\title{
SECRET REGULATION REGULATION OF TRADE IN INDONESIA
}

\author{
Murti Ningsih \\ 1651100124P \\ Fakultas Komputer, 448757202 \\ murtiningsih.student@umitra.ac.id
}

\begin{abstract}
Indonesia is one of the countries that participated in ratifying TRIPs through Law No.7 of 1994 concerning Ratification of the Establishment of the World Trade Organization (WTO). As a consequence, Indonesia has an attachment to implementing the provisions in TRIPs which regulate the Intellectual Property Rights. Direct implementation of this policy, Indonesia has legislation in the areas of Copyright, Patents, Brands, Trade Secrets, Industrial Designs and Integrated Circuit Layout Designs.
\end{abstract}

With regard to the birth of Law No.30 of 2000 concerning Trade Secrets, as one of the implementations of GATT TRIPs. Actually it does not mean that there were no laws and regulations regarding this matter beforehand. This regulation already exists only but these regulations have not been grouped as part of Intellectual Property Rights. Arrangements regarding the protection of Trade Secrets when referring to the TRIPs Agreement are regulated in Part II, namely: "Standard Concerns on Accessibility, Scope and Use of Intellectual Property Rights, listed in Section 1, Article 9 through Section 8, Article 40. include provisions as The following are: Copyright and Related Rights, Trademarks, Geographical Indications, Indistrial Indications, Patents, Layout-Design (Topographies) of Integrated Circuits, Protection of Undisclosed Information, Control of Anti-Competitive Practice in Contractual Licenses.

If you pay attention, actually there is no explicit protection for trade secrets, except for the provisions listed in section 7 regarding Undisclosed Information Protection. This article is then matched to become a Trade Secret. When viewed from other countries, actually not all have specific regulations regarding trade secrets, such as Australia, regulating trade secret provisions in breach of contracts and breach of confident, the United States only has regulations at the state level while at the federal level to date not yet exist, because this problem is also considered as a matter of civil matters only. The existence of a special law that regulates trade secrets, is expected to provide protection for the owners of trade secret rights so that they will spur and improve creativity or innovation in general, in order to develop their business. In addition, there is hope that it can overcome preventive and repressive fraud competition from fraudulent competitors who ignore the development of creativity and innovation.

Keywords: Trade Secrets and TRIPs. 


\section{A. INTRODUCTION}

\section{Definition of Trade Secrets}

Trade secrets are information that is not known to the public in the field of technology and / or business where it has economic value because it is useful in business activities, and is kept confidential by the owner of a trade secret. As stated in Article 1 of the Trade Secret Law (Law Number 30 of 2000) which reads, Trade Secret is information that is not known by the public in the field of technology and / or business, has economic value because it is useful in business activities, and kept confidential by the owner of the Trade Secret. The scope of protection of trade secrets includes production methods, processing methods, sales methods, or other information in the field of technology and / or business that has economic value and is not known by the general public. Trade secrets are protected if the information is:

a) Confidential only known by certain parties not generally by the community.

b) Has economic value if it can be used to carry out commercial activities or businesses or can increase economic profits.

c) Annya Confidentiality is maintained if the owner or the parties who control him have taken appropriate and appropriate steps. Owners of trade secrets can give licenses to other parties. License means a permit granted to another party through an agreement based on the granting of rights (not the transfer of rights) to enjoy economic benefits from a trade secret that is given protection for a certain period of time and certain conditions. Not considered a violation of trade secrets if:

d) Disclose public security, health or safety interests.

e) Re-engineering of products produced by the confidential use of others is done solely for the benefit of further development of the product concerned.

The regulation of trade secrets in Indonesia is still new. The basis of this arrangement is the ratification of the Agreement Establishing the World Trade Organization (approval of the establishment of a World Trade Organization or WTO) which also includes the Agreement on Trade Related Aspects of Intellectual Property Rights (TRIPs Agreement) with Law No. 7 of 1994 so that it is necessary to regulate trade secrets. In Indonesia, trade secrets are first regulated through Law No. 30 of 2000 concerning Trade Secrets. Initially legal protection concerning all forms of unfair competition practices was regulated by signs and norms in Article 1365 of the Civil Code and Article 382 of the Criminal Code.

But then it became a problem after it was packaged as an intellectual property product. This means that the 
concept of unfair competition as a general law is more narrowed or focused on laws that protect fraudulent practices with commercial motives. These requirements are formulated in Law No. 30 of 2000 concerning Trade Secrets. In general it can be said that this trade secret law also complements Law No. 5 of 1999 concerning Prohibition of Monopolistic Practices and Unfair Business Competition.

\section{Trade Secrets Getting Protection}

The need for legal protection against trade secrets is also in accordance with one of the provisions in the Agreement on Trade Related Aspects of Intellectual Property Rights (TRIPs Agreement) which is an attachment of the Agreement Establishing the World Trade Organization on Trade Organizations, as already ratified by Indonesia with Law No. 7 of 1994. The existence of such protection will encourage the birth of new findings or inventions which, although treated confidentially, still receive legal protection, both in terms of ownership, control, and utilization by the inventor. To manage the Trade Secret administration, the government is currently appointing the Ministry of Justice and Human Rights c.q. Directorate General of Intellectual Property Rights to do services in the field of Intellectual Property Rights.

Trade Secret Law No. 30 of 2000 provides the scope of trade secret protection, which includes production methods, processing methods, sales methods, or other information in the field of technology and / or business that has economic value and is not known by the general public. A Trade Secret will get protection if the information is actually confidential, has economic value, and is kept confidential through appropriate efforts.

- It is confidential, meaning that the information is only known by certain parties or is not generally known by the public.

- Having economic value, meaning that the confidentiality of this information can be used to carry out business activities that are commercial in nature or can increase profits economically.

- Information is considered to be kept confidential if the owner or the parties who control it have taken appropriate and appropriate steps.

In the realm of IPR, basically the protection is based on the recognition of the right to wealth and the right to enjoy that wealth within a certain time. This means that during certain times the owner or right holder of IPR can allow or prohibit to know or disseminate information (Trade Secrets).

Violation of Trade Secrets occurs when a person intentionally discloses a Trade Secret, denies an agreement or denies written or unwritten obligations to safeguard the relevant Trade Secret. 
To overcome the violation, legal protection is needed for the owner and / or holder of the IPR concerned.

If someone feels the other party has violated the Trade Secret rights he has, then he as the holder of the Trade Secret or other party as the licensee can sue anyone who is intentionally and without the right of the Trade Secret. For example, according to article 4 of UURD "the owner of the Trade Secret has the right to use his own Trade Secret, give a license or prohibit other parties from using Trade Secrets or disclose the Trade Secret to third parties for commercial purposes". Regarding the article, the claim that we submitted can be a claim for compensation and / or termination of all acts. And different from other IPR claims, the lawsuit regarding the matter of the Trade Secret is submitted to the District Court. In connection with the above, it must also be determined when actually an act is said to have violated the Trade Secret of another person or party. A person is considered to violate the trade secrets of another party if he obtains or controls the Trade Secret in a manner that is contrary to the applicable laws and regulations.

\section{Trade Secret Law in Indonesia}

Indonesia now has a regulation on trade secrets contained in Law No. 30 of 2000 concerning Trade Secrets (hereinafter referred to as the Trade Secret Law) which was promulgated by the Government on December 20, 2000. This law was created in order to advance industries that are able to compete national and international trade, where there is a need to guarantee protection of trade secrets, especially from fraudulent competition. The birth of the Trade Secret Law is also important to ensure effective protection of ownership, control and use of trade secrets as a consequence of Indonesia's participation in the agreement on the Trade Aspects of the Right to Intellectual Property (IPR).

Article 1 number 2 of the Trade Secret Law states that the right to trade secrets is the right to trade secrets that arise under this trade secret law (Law No. 30 of 2000 concerning Trade Secrets). These trade secret rights are classified as property rights, so that as property rights, trade secrets can be transferred and transferred to other parties. The Trade Secret Law in Article 5 paragraph (1) mentions legal events that can result in the transfer of trade secret rights. The transfer of trade secrets can be done through inheritance, grants, wills, written agreements, or other reasons justified by the laws and regulations.

Especially for the transfer of rights on the basis of an agreement, a transfer of rights is needed based on the making of a deed, especially an authentic deed. This is important considering the aspects that are reached so broadly and intricately, in 
addition to safeguarding the interests of each party that enters into an agreement to transfer rights to the trade secret. The transfer of trade secret rights caused by "other reasons justified by the laws and regulations" can be explained here, for example court decisions concerning bankruptcy. In addition, the owner of trade secrets or trade secret rights holders can also give licenses to other parties based on license agreements to carry out or use trade secret rights in commercial activities. In contrast to agreements that are the basis for the transfer of trade secrets, licenses only provide limited rights and limited time. Thus, the license is given for the use or use of trade secrets within a certain period.

Based on the consideration that the nature of trade secrets is closed to other parties, the implementation of licenses is carried out by sending or directly assisting experts who can maintain the trade secrets. This is different, for example, from the provision of technical assistance which is usually carried out in the context of project implementation, operation of new machinery or other activities specifically designed for technical assistance.

While providing a license, the owner of a trade secret may still carry out his own or give a license to a third party regarding his trade secrets. Thus in principle the license agreement is non-exclusive, meaning that it still allows the owner of the trade secret to give licenses to other third parties. If it is desirable for an exclusive license agreement, meaning that the right to trade secrets cannot be given to another third party then it must be stated explicitly in the said license agreement.

For the record, it should be stated in principle that the licensing agreement should not contain provisions that directly or indirectly harm the Indonesian economy, or contain provisions that result in unfair business competition as stipulated in the applicable legislation.16 Legislation is referred to in the provisions this is Law No. 5 of 1999 concerning Prohibition of Monopolistic Practices and Unfair Business Competition. In the administration or recording mechanism, both various forms of transfer of trade secret rights and trade secret license agreements must be registered with the Directorate General of Intellectual Property Rights (IPR).

Provisions regarding compulsory registration will not open the access of publicized trade secrets, because what is listed is not the substance of trade secrets, but only administrative data from rights transfer documents and license agreement documents. This compulsory record is stated in Article 5 paragraph (3) in conjunction with Article 8 paragraph (1) of the Trade Secret Law. Similarly, announcements made on the transfer of trade secret rights and license 
agreements in the Official Trade Secret News, also do not include matters of a substantial nature but only administrative data. Both the transfer documents of trade secret rights and license documents that are not listed to the Directorate General of Intellectual Property Rights will have consequences that without recording the said documents will not have legal consequences for third parties. In addition, it can be stated that the government itself has not yet had an implementing regulation regarding the recording of license agreements. This is a very basic weakness because the existing Patent, Trademark and Copyright Law has ordered this regulation.

\section{B. CONCLUSION}

Based on the discussion from the previous chapter conclusions can be taken as follows:

a. Trade Secret is information that is not known by the public in the field of technology and / or business, has economic value because it is useful in business activities, and is kept confidential by the owner of the Trade Secret.

b. In the realm of IPR, basically the protection is based on the recognition of the right to wealth and the right to enjoy that wealth within a certain time. This means that during certain times the owner or right holder of IPR can allow or prohibit to know or disseminate information (Trade Secrets). c. If someone feels the other party has violated the trade secret rights he has, then he as the right holder of the Trade Secret or other party as the licensee can sue

d. The lawsuit that we submit can be a compensation claim and / or termination of all actions.

\section{ACKNOWLEDGEMENT}

University Of Indonesia

University Of Mitra Indonesia

Telkom University

University Of Mellbourne

Saitama University

\section{REFERENCE (Based ISO 690)}

[1] A. S. Putra And O. M. Febriani, "Knowledge Management Online Application In Pdam Lampung Province," In Prosiding International Conference On Information Technology And Business (Icitb), 2018, Pp. 181187.

[2] A. S. Putra, O. M. Febriani, And B. Bachry, "Implementasi Genetic Fuzzy System Untuk Mengidentifikasi Hasil Curian Kendaraan Bermotor Di Polda Lampung," J. Sist. Inf. Dan Manaj. Basis Data, Vol. 1, No. 1, Pp. 21-30, 2018.

[3] O. M. Febriani And A. S. Putra, "Sistem Informasi Monitoring Inventori Barang Pada Balai Riset Standardisasi Industri Bandar Lampung," J. Inform., Vol. 13, No. 1, Pp. 90-98, 2014.

[4] Putra, Arie Setya. "2018 Artikel Struktur Data, Audit Dan Jaringan Komputer." (2018). 
[5] Putra, A. S. (2018, July 17). Paperplain Fundamental Create Application With Borland Delphi 7.0 University Of Mitra Indonesia. Retrieved From Osf.Io/Pbrn9.

\section{E. REFERENCE (Based APA)}

Putra, A. S., Aryanti, D. R., \& Hartati, I. (2018, November). Metode SAW (Simple Additive Weighting) sebagai Sistem Pendukung Keputusan Guru Berprestasi (Studi Kasus: SMK Global Surya). In Prosiding Seminar Nasional Darmajaya (Vol. 1, No. 1, pp. 85-97).

Sari, D. P., Febriani, O. M., \& Putra, A. S. (2018, November). Perancangan Sistem Informasi SDM Berprestasi pada SD Global Surya. In Prosiding Seminar Nasional Darmajaya (Vol. 1, No. 1, pp. 289-294).

Putra, A. S. (2018). Paperplain: Execution Fundamental Create Application With Borland Delphi 7.0 University Of Mitra Indonesia.

Putra, A. S., Sukri, H., \& Zuhri, K. Sistem Monitoring Realtime Jaringan Irigasi Desa (JIDES) Dengan Konsep Jaringan Sensor Nirkabel. IJEIS (Indonesian Journal of Electronics and Instrumentation Systems), 8(2), 221232.

Darmawan, A., Yuliawati, D., Marcella, O., \& Firmandala, R. (2016). Sistem Absensi dan Pelaporan Berbasis Fingerprint dan SMS Gateway. EXPLORE, 7(1).
Febriani, O. M., Wahyuni, T., \& Yusuf, S. (2017). DESIGN OF WEBSITE-BASED INFORMATION SYSTEM FOR EDOCUMENT ADMINISTRASI IN THE COMMUNITY SERVICE UNIT (A Case Study at Rajabasa District). INTERNATIONAL JOURNAL OF COMPUTERS \& TECHNOLOGY, 16(7), 7010-7020.

Febriani, O. M., \& Wahyuni, T. (2017, October). PERANCANGAN SISTEM E-DOCUMENT ADMINISTRASI LOGBOOK PENELITIAN PADA UNIT LAYANAN DI BANDAR LAMPUNG. In Prosiding Seminar Nasional Darmajaya (Vol. 1, No. 1, pp. 187-194).

Febriani, O. M., \& Permadi, A. B. (2017). Implementasi Sistem Aplikasi Data Bimbingan dan Pelanggaran Siswa pada Sekolah Menengah Atas di Lampung Tengah dengan Metode Analisis dan Desain Sistem Terdistribusi (SSAD). EXPERT, 7(1).

Febriani, O. M., \& Ambarwati, L. (2015). PERANCANGAN APLIKASI PENGOLAHAN DATA PENJUALAN UKM KELANTING KHAS TELO DESA SIDOHARJO KECAMATAN JATI AGUNG KABUPATEN LAMPUNG SELATAN. Jurnal Teknologi Informasi dan Bisnis Pengabdian Masyarakat Darmajaya, 1(1), 77-95.

Febriani, O. M. (2015). Rancang Bangun Aplikasi Ecommercemenggunakan Freewebstore pada UKM Kelanting di Desa Sidoharjo Lampung Selatan. Prosiding Sembistek 2014, 1(02), 446-458. 